\title{
Fysisk anstrengelse kan gi høye troponinverdier
}

\author{
Troponinmålinger er viktig ved mistanke om akutt hjerteinfarkt. Mange andre forhold som påvirker hjertet \\ kan gi forhøyede troponinverdier, bl.a. ekstreme fysiske anstrengelser. Nyere studier har vist at også mer \\ normal fysisk aktivitet kan medføre troponinstigning hos friske mennesker.
}

ab

Engelsk oversettelse av hele artikkelen på www.tidsskriftet.no

I forløpet av akutt koronarsykdom kommer det troponinstigning som følge av cellenekrose, etterfulgt av fall. Målinger av troponin $\mathrm{T}$ eller troponin I i gjentatte blodprøver er blitt en hjørnestein i moderne diagnostikk av akutt hjerteinfarkt. Forhøyede troponinverdier er ikke ensbetydende med akutt koronarsykdom, det kan også ses ved nyresvikt, toksiske medikamenteffekter og autoimmune tilstander og er beskrevet ved akutt hjertesvikt, takykardi, myokarditt, sepsis og lungeemboli (1).

Nye, høysensitive metoder for troponinmåling er blitt tilgjengelige de siste par år. Disse metodene gir gode målinger godt inn i normalområdet og er karakterisert ved analytisk variasjon lik eller bedre enn $10 \%$ rundt øvre referanseområde for friske. Man benytter 99-prosentilen som øvre referansegrense, som innbefatter det området som $99 \%$ av den friske voksne befolkning vil ligge innenfor. Skal troponinmålingene gi støtte til diagnosen akutt hjerteinfarkt, må minst én av verdiene være over 99-prosentilen (2) og det må foreligge signifikant stigning/fall over tid.

Det hersker stor usikkerhet om hva som er klinisk signifikant stigning og fall av troponinnivå. For ikke å tape diagnostisk spesifisitet må endringen være større enn den variasjonen som forekommer ved kombinasjon av analytisk og biologisk variasjon. Den biologiske variasjonen har vært vanskelig å definere. Dette kan ha flere årsaker. Blant annet er det ikke tatt hensyn til hvilke faktorer i dagliglivet som påvirker troponinutskillingen (3-5).

Troponinstigning ved fysisk aktivitet Ekstreme fysiske påkjenninger som maraton- og ultramaratonløp kan føre til forbigående troponinstigning $(6,7)$. I nyere studier er det også vist at mer normal fysisk aktivitet kan medføre troponinstigning hos friske mennesker. I en liten studie med ungdommer fikk mer enn halvparten av deltakerne troponinøkning etter basketballtrening (8). Det samme er rapportert etter gangmattetest $(9,10)$. I en studie med hjertefriske middelaldrende helsearbeidere som ble belastet til nådd ytegrense på sykkel, fikk snaut halvparten troponinøkning i timene etter avsluttet arbeids-EKG (11). I disse studiene overskred troponinverdien metodens 99-prosentil hos flere. Slike forhøyede verdier kan derfor, hvis pasienten rapporterer brystsmerter etter belastningen, formelt oppfylle kriteriene for akutt hjerteinfarkt.

Den underliggende mekanismen for troponinutslipp etter fysisk belastning er ikke avklart. Myokardnekrose er lite sannsynlig (12). Studier har vist at maksimal troponinverdi kommer raskere etter fysiske belastningen $(4 t)(9,11)$ enn ved ablasjon $(8 t)$ (13) og hjerteinfarkt. Dette tyder på at troponin påvist etter fysisk anstrengelse må komme fra myocyttenes cytosol og ikke fra de tynne filamentene i det kontraktile apparat, som ved myokardnekrose. $\mathrm{T}^{1 / 2}$ angis til 3-5 døgn (14).

Vi tror at troponinandelen i cytosol kan passe med at troponin er frigjort fra filamentene til normal nedbrytning. Veltrente vil ha større kontraktilt apparat enn utrente og vil derfor også ha større mengde troponin i cytosol.

\section{«Friske mennesker kan få troponinstigning i blodet etter moderat fysisk anstrengelse»}

\section{Konklusjonen}

Friske mennesker kan få troponinstigning i blodet etter moderat fysisk anstrengelse. I noen tilfeller kan disse verdiene overstige beslutningsnivåene som brukes ved akutt hjerteinfarkt. Dette har konsekvenser for vurderingen av pasienter med akutte brystsmerter. Man bør spørre pasienter med moderat troponinstigning og usikre funn om de har drevet fysisk aktivitet i nær tilslutning til prøvetakingstidspunktet.

\section{Stefan Agewall}

stefan.agewall@medisin.uio.no

Hjerteklinikken

Oslo universitetssykehus

og

Institutt for klinisk medisin

Universitetet i Oslo

\section{Solve Tjora}

Avdeling for medisinsk biokjemi

Oslo universitetssykehus, Aker
Stefan Agewall (f. 1960) er professor og overlege ved Hjerteklinikken, Oslo universitetssykehus. Han er tidligere sjef for hjerteintensiven ved Karolinska Universitetsjukhuset,

Stockholm.

Ingen oppgitte interessekonflikter.

Solve Tjora (f. 1945) er overlege og spesialist i medisinsk biokjemi.

Ingen oppgitte interessekonflikter.

\section{Litteratur}

1. Agewall S, Giannitsis E, Jernberg T, Katus H. Troponin elevation in coronary vs. non-coronary disease. Eur Heart J 2011; 32: 404-11.

2. Thygesen K, Alpert JS, White HD. Universal definition of myocardial infarction. J Am Coll Cardiol 2007; 50: 2173-95.

3. Vasile VC, Saenger AK, Kroning JM et al. Biological and analytical variability of a novel high sensitivity cardiac troponin T assay. Clin Chem 2010; 56 : 1086-90.

4. Jaffe AS, Apple FS. Refining our criteria. Am J Clin Pathol 2009; 131: 11-3.

5. Aakre KM, Sandberg S. Can changes in troponin results be useful in diagnosing myocardial infarction? Clin Chem 2010; 56: 1047-9.

6. Regwan S, Hulten EA, Martinho S et al. Marathon running as a cause of troponin elevation: a systematic review and meta-analysis. J Interv Cardiol 2010; 23: 443-50

7. Giannitis E, Roth HJ, Leithäuser RM et al. New highly sensitive assay used to measure cardiac troponin T concentration changes during a continuous 216-km marathon. Clin Chem 2009; 55 : $590-2$.

8. Nie J, Tong TK, Shi $Q$ et al. Serum cardiac troponin response in adolescents playing basketball. Int J Sports Med 2008; 29: 449-52.

9. Shave R, Baggish A, George K et al. Exerciseinduced cardiac troponin elevation. J Am Coll Cardiol 2010; 56: 169-76.

10. Shave R, Ross P, Low D et al. Cardiac troponin I is released following high-intensity short-duration exercise in healthy humans. Int J Cardiol 2010; 145: $337-9$

11. Tjora S, Gjestland H, Mordal S et al. Troponin rise in healthy subjects during exercise test. Int J Cardiol 2011; 151: 375-6.

12. Bergmann O, Bhardwaj RD, Bernard S et al. Evidence for cariomyocyte renewal in humans. Science 2009; 324: 98-102.

13. Del Rey J, Madrid AH, Valiño JM et al. Cardiac troponin I and minor cardiac damage: biochemical markers in a clinical model of myocardial lesions. Clin Chem 1998; 44: 2270-6.

14. Willis MS, Schisler JC, Portbury AL et al. Build it up - tear it down: protein quality control in cardiac sarcomere. Cardiovascular Res 2009; 81: 439-48.

Mottatt 20.7. 2011, første revisjon innsendt 6.10. 2011, godkjent 13.10. 2011. Medisinsk redaktør Petter Gjersvik. 